\title{
Volume Gástrico Residual e Risco de Aspiração Pulmonar em Crianças com Refluxo Gastroesofágico. Estudo Comparativo *
}

\section{Residual Gastric Volume and Risk for Pulmonary Aspiration in Children with Gastroesophageal Reflux. Comparative Study}

Marcos Guilherme Cunha Cruvinel, TSA ${ }^{1}$; Paulo Fernando Souto Bittencourt ${ }^{2}$; José Roberto de Rezende Costa, TSA ${ }^{3}$; Paulo Roberto Vieira Barbosa ${ }^{4}$

\section{RESUMO}

Cruvinel MGC, Bittencourt PFS, Costa JRR, Barbosa PRV Volume Gástrico Residual e Risco de Aspiração Pulmonar em Crianças com Refluxo Gastroesofágico. Estudo Comparativo

JUSTIFICATIVA E OBJETIVOS: Freqüentemente, crianças com refluxo gastroesofágico têm que ser submetidas a anestesia para estudos diagnósticos e/ou procedimentos cirúrgicos. Considera-se que o esvaziamento gástrico seja retardado na doença do refluxo gastroesofágico pediátrico. Portanto, a anestesia nesses pacientes tem aspectos peculiares, especialmente no que se refere ao risco de aspiração pulmonar. O objetivo deste estudo é comparar o volume gástrico residual de crianças com ou sem refluxo gastroesofágico e determinar se as crianças com refluxo têm, de fato, risco aumentado para a aspiração pulmonar do conteúdo gástrico durante a anestesia.

MÉTODO: Participaram do estudo 38 crianças, estado físico ASA I ou II, submetidas à endoscopia digestiva alta diagnóstica. As crianças foram divididas em dois grupos: grupo $R$, portadoras de refluxo gastroesofágico e grupo $N$, sem refluxo gastroesofágico com endoscopia digestiva alta normal. Durante o procedimento, todo o conteúdo gástrico foi aspirado e seu volume medido.

RESULTADOS: Das 38 crianças estudadas, 18 (47\%) foram incluídas no grupo $R$ e 20 (53\%) no grupo $N$. Não foram constatadas diferenças significativas entre os dois grupos no que se refere à idade, ao peso e tempo de jejum. Em todos os pacientes, o volume gástrico residual observado foi inferior a $0,4 \mathrm{ml} \cdot \mathrm{kg}^{-1}$; e não houve diferenças significativas entre os grupos.

CONCLUSÕES: Nas condições deste estudo, o volume gástrico residual não diferiu entre as crianças portadoras, ou não, de refluxo gastroesofágico. Portanto, as crianças com

\footnotetext{
* Recebido dos (Received from) Departamentos de Anestesiologia e Endoscopia dos Hospitais Mater Dei e Felício Rocho, Belo Horizonte, MG

1. Anestesiologista dos Hospitais Mater Dei e Governador Israel Pinheiro (IPSEMG), Especialista em Clínica Médica

2. Especialista em Pediatria pela SBP, Pediatra e Endoscopista dos Hospitais Mater Dei, HC-UFMG/Instituto Alfa de Gastrenterologia e Felício Rocho, Mestre em Pediatria pela UFMG

3. Anestesiologista do Hospital Mater Dei e Gastrocenter, Mestre em Farmacologia pela UFMG

4. Anestesiologista do Hospital Felício Rocho
}

Apresentado (Submitted) em 18 de fevereiro de 200377

Aceito (Accepted) para publicação em 28 de maio de 2003

Endereço para Correspondência (Correspondence to)

Dr. Marcos Guilherme Cunha Cruvinel

Rua Simão Irffi, 86/301 - Bairro Coração de Jesus

30380-270 Belo Horizonte, MG

E-mail:marcoscruvinel@uai.com.br

(c) Sociedade Brasileira de Anestesiologia, 2004 refluxo gastroesofágico não apresentaram risco aumentado de aspiração pulmonar, quando comparadas a crianças sem refluxo gastroesofágico, podendo-se dispensar sua profilaxia.

Unitermos: ANESTESIA, Pediátrica; COMPLICAÇÕES, aspiração pulmonar: DOENÇAS: refluxo gastroesofágico

\section{SUMMARY}

Cruvinel MGC, Bittencourt PFS, Costa JRR, Barbosa PRV - Residual Gastric Volume and Risk for Pulmonary Aspiration in Children with Gastroesophageal Reflux. Comparative Study

BACKGROUND AND OBJECTIVES: Children with gastroesophageal reflux are often submitted to anesthesia for both diagnostic and therapeutic procedures. They are considered as having delayed gastric emptying and so anesthesia in this group is surrounded by special consideration, mostly with regard to pulmonary aspiration. This study aimed at comparing residual gastric volume of children with and without gastroesophageal reflux and at determining if children with gastroesophageal reflux are at risk for pulmonary aspiration during anesthesia.

METHODS: Participated in this study 38 children, physical status ASA I and II undergoing upper digestive diagnostic endoscopy. Children were distributed in two groups, according to the presence (group R) or absence (group N) of gastroesophageal reflux. All gastric content was collected and measured during the procedure.

RESULTS: There were 18 (47\%) group R children and 20 (53\%) group $N$ children. Age, weight and fasting time were not significantly different between groups. In all patients, residual gastric volume was less then $0,4 \mathrm{ml} . \mathrm{kg}^{-1}$ and there were no significant differences between groups.

CONCLUSIONS: Children with gastroesophageal reflux were not at increased risk for pulmonary aspiration, as compared to children without reflux. Therefore, its prophylaxis would not be necessary.

Key Words: ANESTHESIA, Pediatric; COMPLICATIONS, pulmonary aspiration: DISEASES, gastroesophageal reflux

\section{INTRODUÇÃO}

A doença do refluxo gastroesofágico é prevalente tanto em adultos quanto em crianças $(7 \% \text { a } 10 \%)^{1}$. Portanto, não se estranha que freqüentemente crianças com esta afecção tenham que se submeter à anestesia para estudos diagnósticos e/ou procedimentos cirúrgicos. A anestesia nesses pacientes tem aspectos peculiares, especialmente no que se refere ao risco de aspiração pulmonar. A aspiração pulmonar do conteúdo gástrico é considerada, há muito tempo, como uma causa de morbidade e mortalidade em pacientes submetidos à anestesia ${ }^{2,3}$. O objetivo deste estudo foi comparar o volume gástrico residual de crianças com 
ou sem refluxo gastroesofágico e determinar se as portadoras de doença do refluxo gastroesofágico têm risco aumentado para aspiração pulmonar do conteúdo gástrico durante a anestesia.

\section{MÉTODO}

Após aprovação pela Comissão de Ética e consentimento pós-informado dos pais, participaram do estudo 38 crianças, estado físico ASA I ou II, submetidas à endoscopia digestiva alta diagnóstica. Excluíram-se aquelas que apresentaram qualquer distúrbio esofágico, gástrico ou duodenal, exceto refluxo gastroesofágico, além daquelas com distúrbios hormonais ou renais, e com afecções congênitas. As crianças foram divididas em dois grupos: grupo $R$, portadoras de refluxo gastroesofágico e grupo $\mathrm{N}$, não portadoras de refluxo gastroesofágico e com endoscopia digestiva alta normal. Crianças encaminhadas para esclarecimento de dor abdominal ou vômitos, nas quais o estudo endoscópico foi normal constituíram o grupo N. Dois pacientes que se apresentaram com tal objetivo portavam esofagite e foram incluídos no grupo R. O diagnóstico da doença do refluxo gastroesofágico dos demais componentes do grupo $\mathrm{R}$ baseou-se no quadro clínico e exames complementares; como pHmetria, cintilografia, estudo radiológico contrastado esôfago-gástrico e pela própria endoscopia digestiva alta, quando nesta era evidente a esofagite. As orientações de jejum foram dadas aos responsáveis pelas crianças em consulta prévia, segundo a tabela I. Todas elas se submeteram à anestesia geral com intubação orotraqueal e monitorização com estetoscópio precordial, oxímetro de pulso e eletrocardiograma. Todo o conteúdo gástrico foi aspirado e seu volume medido.

\begin{tabular}{lc} 
Tabela I - Orientações Quanto ao Tempo de Jejum & \\
\hline Líquidos transparentes (sem resíduos) & 2 horas \\
Leite humano & 4 horas \\
Leite de fórmulas & 6 horas \\
Leite não humano & 6 horas \\
Alimentos sólidos & 6 horas \\
\hline
\end{tabular}

Compararam-se os dois grupos quanto ao sexo utilizando o teste Exato de Fisher. Para avaliar as diferenças entre eles referentes à idade, peso, tempo de jejum e volume gástrico residual utilizou-se o teste $t$ de Student. Todos os resultados foram considerados significativos para uma probabilidade de significância inferior a $5 \%(p<0,05)$.

\section{RESULTADOS}

Das 38 crianças estudadas, 18 (47\%) foram incluídas no grupo R e 20 (53\%) no grupo N. Uma criança pertenceria ao grupo N; entretanto, apresentava alimentos sólidos no estômago, e sua mãe, apesar de ter afirmado inicialmente que a criança se encontrava em jejum, acabou relatando, posterior- mente, a não observância das orientações quanto ao mesmo. Excluiu-se, portanto, esta criança do estudo.

Não foram constatadas diferenças significativas entre os dois grupos no que se refere à idade, sendo que a média do grupo $\mathrm{R}$ foi 47,7 meses e do grupo N 55,5 meses. Os grupos também foram similares em relação à média de peso (grupo R: $15 \mathrm{~kg}$ e grupo N: 18,4 kg). O tempo médio de jejum no grupo $\mathrm{R}$ foi de 9,1 horas, enquanto no grupo $\mathrm{N}$ foi de 9,6 horas, sem diferença estatisticamente significativa.

Em todos os pacientes, o volume gástrico residual observado foi inferior a $0,4 \mathrm{ml} . \mathrm{kg}^{-1}$, sendo que no grupo R houve variação de 0 a $0,38 \mathrm{ml} \cdot \mathrm{kg}^{-1}$, com média igual a $0,10 \mathrm{ml} \cdot \mathrm{kg}^{-1}$, enquanto que no grupo $\mathrm{N}$ essa variação foi de 0 a $0,27 \mathrm{ml}^{\mathrm{kg}} \mathrm{kg}^{-1}$, com média igual a $0,09 \mathrm{ml} \mathrm{kg}^{-1}$. Não há, também, diferenças significativas entre os grupos (Tabela II).

Tabela II - Caracterização das Crianças Segundo o Volume Gástrico Residual

\begin{tabular}{lccc}
\hline Grupos & \multicolumn{3}{c}{ Medidas Descritivas $\left(\mathrm{ml}^{\mathrm{k}} \mathrm{kg}^{-1}\right)$} \\
\hline $\mathrm{R}(\mathrm{n}=18)$ & Mínimo & Máximo & Média \pm DP \\
$\mathrm{N}(\mathrm{n}=20)$ & 0,0 & 0,38 & $0,10 \pm 0,03$ \\
\hline
\end{tabular}

\section{DISCUSSÃo}

Nem sempre se recomendou o jejum pré-operatório. Seu surgimento se relaciona diretamente à descrição da aspiração pulmonar do conteúdo gástrico e suas conseqüências ${ }^{3}$. Curiosamente, até o final do século XIX, os pacientes eram orientados a tomar chá duas horas antes da indução da anestesia $^{3}$. O aparecimento da recomendação de jejum pré-operatório não é fácil de ser determinado, porém sua popularização se deu após 1946, quando Mendelson relatou a relação entre a alimentação e a aspiração durante o parto ${ }^{2}$. A partir desse relato, surgiu a idéia da instituição do jejum para adequado esvaziamento gástrico, visando assim a redução do risco de pneumonite de aspiração, tornando-se tão razoável que tal recomendação se alastrasse. A dúvida passou a girar acerca do tempo de jejum necessário para que o estômago se esvazie adequadamente.

No entanto, para responder a essa pergunta havia necessidade de se determinar qual volume seria suficiente para causar pneumonite química. Desde a descrição de Mendelson já se sabia que o $\mathrm{pH}$ do líquido aspirado era fundamental no desenvolvimento da síndrome ${ }^{3}$. A gravidade da lesão pulmonar é maior quanto mais ácido for líquido aspirado. Portanto, quanto mais ácido, menor é o volume necessário para causar lesão pulmonar ${ }^{4}$. Roberts e col. publicaram, em 1974, um editorial definindo que um volume gástrico residual de 0,4 $\mathrm{ml} . \mathrm{kg}^{-1}$ e com $\mathrm{pH}$ menor que 2,5 seria suficiente para o desenvolvimento da síndrome descrita por Mendelson ${ }^{5}$. Vários estudos foram feitos na tentativa de confirmar estes valores, baseados em experimentos com macacos Rhesus. No entanto, devido à impossibilidade de serem feitos estudos em humanos e à grande diferença existente entre espécies, a 
extrapolação dos estudos em animais para humanos é potencialmente imprecisa. $\mathrm{O}$ pH e o volume gástrico necessários para causar pneumonite em humanos não ficou estabelecido, além de não se poder determiná-lo diretamente. A definição de Roberts e col. tem sido aceita e baseou a maioria dos estudos subseqüentes sobre o assunto ${ }^{3}$. Importante lembrar que a aspiração de todo o conteúdo gástrico parece improvável, pois todo ele teria que ser regurgitado para o esôfago, e entrar integralmente nos pulmões. Por serem os mais utilizados, embora talvez imprecisos, tem-se os valores de $0,4 \mathrm{ml} . \mathrm{kg}^{-1}$ com $\mathrm{pH}$ menor que 2,5 como necessários para causar pneumonite de aspiração.

Mesmo após jejum adequado, consideram-se alguns pacientes de risco para presença de volume gástrico residual maior que $0,4 \mathrm{ml} . \mathrm{kg}^{-1}$, aos quais se denomina "estômago cheio" (Quadro I) ${ }^{6-11}$. Por mecanismos peculiares a cada um destes grupos, o esvaziamento gástrico é retardado, causando elevado volume gástrico residual, ainda que após jejum adequado. Apesar de alguns estudos conflitantes, o esvaziamento gástrico retardado tem sido associado à doença do refluxo gastroesofágico em crianças ${ }^{12-17}$.

\section{Quadro I - Pacientes de Risco para Estômago Cheio}

Prematuridade e dispnéia

Obesidade

Refluxo gastroesofágico preexistente

Obstrução intestinal

Outras doenças gastrintestinais (p. ex.: estenose de piloro)

Hipertensão intracraniana

Ascite

Tumores intra-abdominais volumosos

Neuropatia autonômica

Ansiedade extrema ou dor intensa

Cirurgia prévia de esôfago

Senilidade

Dentre os pacientes de risco para aspiração pulmonar do conteúdo gástrico, especificamente aqueles com refluxo gastroesofágico, a indução e o despertar da anestesia são cercados de cuidados adicionais ${ }^{3,18-20}$. Tem-se como método preferido de indução nestas situações a indução venosa em seqüência rápida. Precedendo à indução estaria indicado o uso de metoclopramida e bloqueadores $\mathrm{H}_{2}$. Aintubação com paciente acordado e seus respectivos reflexos laríngeos preservados constitui outra alternativa para estes casos. As técnicas de intubação com profilaxia para aspiração pulmonar do conteúdo gástrico são extremamente úteis e im- portantes para aqueles pacientes de risco, tendo resultado em grande diminuição na incidência de aspiração pulmonar, e redução da morbidade e mortalidade da anestesia ${ }^{3}$. Entretanto, elas podem apresentar desvantagens e até mesmo riscos. Em crianças, o estabelecimento de um acesso venoso com o paciente acordado é, com freqüência, trabalhoso, desconfortável e angustiante. Nesses pacientes, a pré-oxigenação com $\mathrm{O}_{2}$ a $100 \%$ por alguns minutos nem sempre é factível, podendo gerar estresse adicional. Asuccinilcolina carrega consigo o fantasma da hipertermia maligna, além de outros efeitos adversos bem estabelecidos, como as bradidisritmias, a hipercalemia e até mesmo assistolia, dentre outras 21 . O rocurônio não apresenta tais efeitos adversos, mas nas doses para intubação traqueal em seqüência rápida (600 $\mu \mathrm{g} \cdot \mathrm{kg}^{-1}$ ), tem duração de efeito prolongado (46 minutos), tornando-o pouco útil em procedimentos rápidos ${ }^{19}$. A metoclopramida e os bloqueadores $\mathrm{H}_{2}$ são drogas que podem apresentar efeitos colaterais, como sintomas extrapiramidais e neuropsíquicos, bem como bradicardia ou liberação de histamina $^{22,23}$. A intubação traqueal com a criança acordada e com reflexos laríngeos preservados é também desconfortável, difícil e geradora de ansiedade. Por estes motivos, tais técnicas só devem ser usadas em pacientes seletos. Seu uso em pacientes sem risco de aspiração pulmonar, além de desnecessário, pode trazer morbidades potencialmente evitáveis.

Portanto, fica claro que, para se produzir pneumonite aspirativa, três condições são necessárias ${ }^{3}$ :

1. Regurgitação (processo passivo e clinicamente silencioso) ou vômito (processo ativo que envolve uma série complicada e coordenada de reflexos);

2. Quantidade suficiente do material regurgitado deve atingir a árvore traqueobrônquica;

3. O conteúdo gástrico deve ser capaz de produzir lesão pulmonar.

No presente estudo, analisou-se um grupo de 18 crianças com diagnóstico bem estabelecido de doença do refluxo gastroesofágico e não se encontrou dentre elas, uma que apresentasse volume gástrico residual capaz de expô-la ao risco de aspiração pulmonar. Ademais, ao se comparar o volume gástrico residual dessas 18 crianças com o daquelas 20 sem refluxo, não se encontraram diferenças significativas.

Nas condições deste estudo, o volume gástrico residual não diferiu entre as crianças portadoras, ou não, de refluxo gastroesofágico. Assim, concluímos que crianças com doença do refluxo gastroesofágico não apresentaram risco aumentado de aspiração pulmonar, quando comparadas às crianças sem doença do refluxo gastroesofágico, podendo-se dispensar sua profilaxia. 


\section{Residual Gastric Volume and Risk for Pulmonary Aspiration in Children with Gastroesophageal Reflux. Comparative Study}

Marcos Guilherme Cunha Cruvinel, TSA, M.D.; Paulo Fernando Souto Bittencourt, M.D.; José Roberto de Rezende Costa, TSA, M.D.; Paulo Roberto Vieira Barbosa, M.D.

\section{INTRODUCTION}

Gastroesophageal reflux is a disease affecting both adults and children (7\% to $10 \%)^{1}$. So, it is not unusual for children with this disease to be submitted to anesthesia for diagnostic and/or surgical procedures. Anesthesia in this group is surrounded by special consideration, mostly with regard to pulmonary aspiration. Pulmonary gastric content aspiration is for a long time considered a cause for morbidity and mortality in patients submitted to anesthesia ${ }^{2,3}$. This study aimed at comparing residual gastric volume in children with and without gastroesophageal reflux and determining whether gastroesophageal reflux children are at increased risk for pulmonary gastric content aspiration during anesthesia.

\section{METHODS}

After the Ethics Committee approval and parents' informed consent, participated in this study 38 children physical status ASA I and II, submitted to upper digestive diagnostic endoscopy. Exclusion criteria were esophageal, gastric or duodenal disorders, except gastroesophageal reflux, in addition to hormonal and renal disorders and congenital diseases. Children were divided in two groups: Group R - with gastroesophageal reflux; and Group $\mathrm{N}$ - without gastroesophageal reflux and with normal upper digestive endoscopy. Children referred for investigation of abdominal pain or vomiting and with normal endoscopic results were allocated to group N. Two patients referred for this same purpose had esophagitis and were included in Group R. Gastroesophageal reflux diagnosis of remaining Group R children was based on clinical presentation and additional tests, such as $\mathrm{pH}$, scintigraphy, enhanced esophageal-gastric radiological investigation and upper digestive endoscopy itself when it clearly showed esophagitis. Fasting directions were given to children's tutors in a previous visit, according to table I. All children were submitted to general anesthesia with tracheal intubation and monitoring with precordial stethoscope, pulse oximetry and ECG. All gastric content has been aspirated and measured.

Table I - Fasting Time Directions ${ }^{9-11}$

\begin{tabular}{ll}
\hline Clear fluids (without residues) & 2 hours \\
Breast milk & 4 hours \\
Formula milk & 6 hours \\
Non-human milk & 6 hours \\
Solid food & 6 hours \\
\hline
\end{tabular}

Fisher's Exact test was used to compare gender between groups. Student's $t$ test was used to evaluate differences in age, weight, fasting time and residual gastric content. All results were considered significant for a significance probability below $5 \%(p<0.05)$.

\section{RESULTS}

From 38 children enrolled in the study, 18 (47\%) were included in Group R and 20 (53\%) were included in Group N. One child who should belong to group $N$ presented solid gastric content and the mother, after having initially stated that the child was on fasting, ended up reporting the non compliance with fasting directions. This child was, then, excluded from the study.

Mean Group R age was 47.7 months and mean Group N age was 55.5 months, without significant difference. Groups were also similar in mean weight (Group R: $15 \mathrm{~kg}$ and Group N: 18.4 $\mathrm{kg}$ ). Mean fasting time for group R was 9.1 hours while for group $\mathrm{N}$ it was 9.6 hours, without statistically significant difference.

Residual gastric content for all patients was below 0.4 $\mathrm{ml} . \mathrm{kg}^{-1}$. Group R has varied 0 to $0.38 \mathrm{ml} . \mathrm{kg}^{-1}$ (mean $=0.10$ $\mathrm{ml} . \mathrm{kg}^{-1}$ ) and Group N has varied 0 to $0.27 \mathrm{ml}^{\mathrm{kg}} \mathrm{kg}^{-1}$ (mean $=0.09$ $\mathrm{ml} . \mathrm{kg}^{-1}$ ), again without significant difference between groups (Table II).

Table II - Classification of Children According to Residual Gastric Content

\begin{tabular}{lccc}
\hline Groups & \multicolumn{3}{c}{ Descriptive Measures $\left(\mathrm{ml}^{\mathrm{k}} \mathrm{kg}^{-1}\right)$} \\
\hline $\mathrm{R}(\mathrm{n}=18)$ & Minimum & Maximum & Mean \pm SD \\
$\mathrm{N}(\mathrm{n}=20)$ & 0.0 & 0.38 & $0.10 \pm 0.03$ \\
\hline
\end{tabular}

\section{DISCUSSION}

Preoperative fasting has not always been recommended and its requirement is directly related to pulmonary gastric content aspiration description and its consequences ${ }^{3}$. Curiously, until late $19^{\text {th }}$ Century, patients were oriented to drink tea two hours before anesthetic induction ${ }^{3}$. The beginning of preoperative fasting recommendation is difficult to establish, but it started to become popular after 1946, when Mendelson has reported the relationship between food and aspiration during labor ${ }^{2}$. As from this report, fasting for adequate gastric emptying started to be recommended to decrease the risk for aspiration pneumonia and it was reasonable that such recommendation would be widespread. The question then became the necessary fasting time for adequate gastric emptying.

However, to answer this question the volume to promote chemical pneumonitis had to be determined. Since Mendelson's description, it was already known that aspired fluid $\mathrm{pH}$ was critical for the development of the syndrome ${ }^{3}$. Pulmonary injury severity increases with the acidity of the asVol. 54, No 1, Janeiro - Fevereiro, 2004 
pired fluid. So, the more acid, the lower the volume needed for pulmonary injury ${ }^{4}$. Roberts et al. have published in 1974 an editorial defining that a residual gastric volume of $0.4 \mathrm{ml} . \mathrm{kg}^{-1}$ with $\mathrm{pH}$ below 2.5 would be enough for the development of the syndrome described by Mendelson ${ }^{5}$. Several studies have attempted to confirm such values, based on Rhesus monkey studies. However, due to the impossibility of human studies and major differences among species, the extrapolation of animal studies to humans is potentially imprecise. Gastric volume and $\mathrm{pH}$ necessary to induce pneumonitis in humans have not been established and it is impossible to directly determine them. Roberts et al.'s definition has been accepted and has been the basis for most subsequent studies on the subject $^{3}$. It is important to remind that aspiration of all gastric content seems to be improbable, because the whole content would have to be regurgitated to the esophagus and totally enter lungs. For being the most widely used, although maybe imprecise, values of $0.4 \mathrm{ml} . \mathrm{kg}^{-1}$ with $\mathrm{pH}$ below 2.5 have been considered enough to cause aspiration pneumonitis.

Even after adequate fasting, some patients are at risk for the presence of residual gastric volume above $0.4 \mathrm{ml} . \mathrm{kg}^{-1}$, whom are called "full stomach" (Chart I) ${ }^{6-11}$. In this group, unique mechanisms delay gastric emptying promoting high residual gastric volume, even after adequate fasting. In spite of some conflicting studies, delayed gastric emptying has been associated to gastroesophageal reflux disease in children ${ }^{12-17}$.

\section{Chart I - Risk Patients for Full Stomach}

\section{Prematurity and dyspnea}

Obesity

Preexisting gastroesophageal reflux

Bowel obstruction

Other GI diseases (e.g.: pylorus stenosis)

Intracranial hypertension

Ascites

Bulk intra-abdominal tumors

Autonomic neuropathy

Extreme anxiety or severe pain

Previous esophageal surgery

Senility

In risk patients for pulmonary gastric content aspiration, specifically those with gastroesophageal reflux, anesthetic induction and emergence require additional care ${ }^{3,18-20}$. Rapid sequence intravenous induction is the preferred method in such situations. Metochlopramide and $\mathrm{H}_{2}$ blockers would be indicated before induction. Intubation with awaken patients and preserved laryngeal reflexes is another alternative for those cases.

Intubation techniques with pulmonary gastric content aspiration prophylaxis are extremely useful and important for risk patients, and have resulted in major decrease in pulmonary aspiration and anesthetic morbidity and mortality ${ }^{3}$. However, they may have disadvantages and even risks. The establishment of a venous access in awaken children is frequently time consuming, uncomfortable and stressing. In those patients, pre-oxygenation with $100 \%$ oxygen for some minutes is not always feasible and may promote additional stress. Succinylcholine bears the burden of malignant hyperthermia, in addition to other well-established side effects, such as bradyarhythmias, hyperkalemia and even asystole, among others ${ }^{21}$. Rocuronium does not have these adverse effects, but in rapid sequence tracheal intubation doses $\left(600 \mu \mathrm{g} . \mathrm{kg}^{-1}\right)$ it has prolonged duration (46 minutes), making it less useful for short procedures ${ }^{19}$. Metochlopramide and $\mathrm{H}_{2}$ blockers may promote side effects, such as extrapiramidal and neurpsychical symptoms, as well as bradycardia or histamine release ${ }^{22,23}$. Tracheal intubation with awaken children and preserved laryngeal reflexes is also uncomfortable, difficult and stressful. For those reasons, such techniques should only be used in selected patients. Its use in patients with no risk for pulmonary aspiration, in addition to be unnecessary, may bring potentially avoidable morbidities.

So, it is clear that three conditions are necessary to promote aspiration pneumonitis ${ }^{3}$ :

1. Regurgitation (passive and clinically silent process) or vomiting (active process involving a complicated and coordinated series of reflexes);

2. Sufficient volume of regurgitated material should reach tracheobronchial tree;

3. Gastric content should be able to produce pulmonary injury.

Our study has evaluated a group of 18 children with well-established diagnosis of gastroesophageal reflux and has not found even one child with residual gastric content enough to expose them to pulmonary aspiration risk. Moreover, in comparing residual gastric content of these 18 children to those 20 children without reflux, no significant differences were found.

In the conditions of our study, residual gastric content has not differed in children with or without gastroesophageal reflux. So, we concluded that children with gastroesophageal reflux are not at an increased risk for pulmonary aspiration as compared to children without gastroesophageal reflux, with no need for prophylaxis.

\section{REFERÊNCIAS - REFERENCES}

01. Vandenplas $Y$, Goyvaerts H, Helven R et al - Gastroesophageal reflux, as assessed by 24-hour $\mathrm{pH}$ monitoring, in 509 healthy infants screened for SIDS risk. Pediatrics, 1991;88:834-840.

02. Mendelson CL - The aspiration of stomach contents into the lungs during obstetric anesthesia. Amer J Obstetrics Gynaecol, 1946;53:191-205.

03. Macuco MV - Jejum pré-operatório: validade de critérios. Rev Bras Anestesiol, 1998;48:295-308. 
04. Grenfield LJ, Singleton RP, McCaffree DR et al - Pulmonary effects of experimental graded aspiration of hydrochloric acid. Ann Surg, 1969;170:74-86.

05. Roberts RB, Shirley MA - Reducing the risk of acid aspiration during cesarean section. Anesth Analg, 1974;53:859-868.

06. Splinter WM, Schreiner MS - Preoperative fasting in children. Anesth Analg, 1999;89:80-89.

07. Phillips S, Daborn AK, Hatch DJ - Preoperative fasting for paediatric anaesthesia. Br Anaesth, 1994;73:529-536.

08. Olsson GL, Hallen B, Hambreaeus-Jonzon K - Aspiration during anaesthesia: a computer aided study of 185358 anesthetics. Acta Anaesthesiol Scand, 1986;30:84-92.

09 . Eriksson LI, Sandin R - Fasting guidelines in different countries. Acta Anaesthesiol Scand, 1996;40:971-974.

10. Ferrari LR, Rooney FM, Rockoff MA - Preoperative fasting practices in pediatrics. Anesthesiology, 1999;90:978-980.

11. A report by the American Society of Anesthesiologists Task Force on Preoperative Fasting. Anesthesiology, 1999;90: 896-905.

12. Cucchiara S, Salvia G, Borreli O et al - Gastric electrical dysrhythmias and delayed gastric emptying in gastroesophageal reflux disease. Am J Gastroenterol, 1997;92: 1103-1108.

13. Di Lorenzo C, Piepz A, Ham H et al - Gastric emptying with gastroesophageal reflux. Arch Dis Child, 1987;62:449-452.

14. Hillemeier A, Lange R, McCallum R et al - Delayed gastric emptying in infants with gastroesophageal reflux. J Pediatr. 1981;98:190-194.

15. McCallum R, Berkowitz D, Lerner E - Gastric emptying in patients with gastroesophageal reflux. Gastroenterology, 1981;80:285-289.

16. Cannon R, Stadalnik R - Postprandial gastric motility in infants with gastroesophageal reflux and delayed gastric emptying. $J$ Nucl Med, 1993;34:2120-2125.

17. Andrés JM, Mathias JR, Clench MH et al - Gastric emptying in infants with gastroesophageal reflux. Dig Dis Sci, 1988;33 393-399.

18. Coté CJ, Todres D, Ryan JF et al - Preoperative Evaluation of Pediatric Patients, em: Coté CJ, Todres D, Ryan JF et al - A Practice of Anesthesia for Infants and Children. $3^{\text {rd }} \mathrm{Ed}$, Philadelphia, Saunders, 2001;37-54.

19. Goudsouzian NG - Muscle Relaxants in Children, em: Coté CJ, Todres D, Ryan JF et al - A Practice of Anesthesia for Infants and Children. $3^{\text {rd }}$ Ed, Philadelphia, Saunders, 2001;196-215.

20. Stoelting RK - Antacids and Gastrointestinal Prokinetics, em: Stoelting RK - Pharmacology and Physiology in Anesthetic Practice. $3^{\text {rd }}$ Ed, Philadelphia, Lippincott-Raven, 1999;444-452.
21. Stoelting RK - Histamine and Histamine Receptor Antagonists, em: Stoelting RK - Pharmacology and physiology in anesthetic practice. $3^{\text {rd }}$ Ed, Philadelphia, Lippincott-Raven, 1999;385-397.

22. Stoelting RK - Antacids and Gastrointestinal Prokinetics, em: Stoelting RK - Pharmacology and Physiology in Anesthetic Practice. $3^{\text {rd }}$ Ed, Philadelphia, Lippincott-Raven, 1999;444-452.

23. Stoelting RK - Histamine and Histamine Receptor Antagonists, em: Stoelting RK - Pharmacology and Physiology in Anesthetic Practice. $3^{\text {rd }}$ Ed, Philadelphia, Lippincott-Raven, 1999;385-397.

\section{RESUMEN}

Cruvinel MGC, Bittencourt PFS, Costa JRR, Barbosa PRV - Volumen Gástrico Residual y Riesgo de Aspiración Pulmonar en Niños con Reflujo Gastroesofágico. Estudio Comparativo

JUSTIFICATIVA Y OBJETIVOS: Frecuentemente, niños con reflujo gastroesofágico tienen que ser sometidos a anestesia para estudios diagnósticos y/o procedimientos quirúrgicos. Se considera que el vaciamiento gástrico sea retardado en la molestia del reflujo gastroesofágico pediátrico. Por tanto, la anestesia en esos pacientes tiene aspectos peculiares, especialmente en lo que se refiere al riesgo de aspiración pulmonar. El objetivo de este estudio es comparar el volumen gástrico residual de niños con o sin reflujo gastroesofágico y determinar si los niños con reflujo tienen, de hecho, riesgo aumentado para la aspiración pulmonar del contenido gástrico durante la anestesia.

MÉTODO: Participaron del estudio 38 niños, estado físico ASA I o II, sometidos a endoscópia digestiva alta diagnóstica. Los niños fueron divididos en dos grupos: grupo $R$, portadores de reflujo gastroesofágico y grupo $N$, sin reflujo gastroesofágico con endoscópia digestiva alta normal. Durante el procedimiento, todo el contenido gástrico fue aspirado y su volumen medido.

RESULTADOS: De los 38 niños estudiados, 18 (47\%) fueron incluidos en el grupo $R$ y 20 (53\%) en el grupo N. No fueron constatadas diferencias significativas entre los dos grupos en lo que se refiere a la edad, al peso y tiempo de ayuno. En todos los pacientes, el volumen gástrico residual observado fue inferior a $0,4 \mathrm{ml} . \mathrm{kg}^{-1}$; y no hubo diferencias significativas entre los grupos.

CONCLUSIONES: En las condiciones de este estudio, el volumen gástrico residual no divergió entre los niños portadores, o no, de reflujo gastroesofágico. Por tanto, los niños con reflujo gastroesofágico no presentaron riesgo aumentado de aspiración pulmonar, cuando comparados a los niños sin reflujo gastroesofágico, pudiendo dispensar su profilaxis. 